\title{
Attitudes of Municipal Officials Toward Street Tree Programs in Pennsylvania, U.S.
}

\author{
Tyler R. Stevenson, Henry D. Gerhold, and William F. Elmendorf
}

\begin{abstract}
Survey responses from 528 officials in 356 municipalities defined the developmental status of municipal street tree programs and the attitudes of three types of officials: elected chief officials, public works administrators, and municipal solicitors. In sustained programs, which had an ordinance, tree commission, inventory, and management plan, officials had more positive attitudes about trees than in developing programs, which had at least one of these elements, or in communities without a tree program. However, even in the latter, approximately half of the officials believed that benefits of street trees outweigh costs and any disadvantages, and $62 \%$ favored starting a tree program. No tree programs exist in $46 \%$ of the cities, $82 \%$ of the boroughs, and $97 \%$ of the townships, so there are many opportunities and also important barriers. Incomplete understanding of the benefits of trees and tree care practices leads to low public support, insufficient funding, and inadequate personnel and equipment. Most officials favor spending some money on trees but regard tree programs as less important than other civic responsibilities. Officials may be persuaded to start or improve tree programs by explaining benefits more fully and how public safety can be improved by proper pruning, inventories that locate dangerous trees, and management plans that arrange to remove them. Furthermore, funding may be alleviated by using volunteers, grants, and available technical advice.
\end{abstract}

Key Words. Attitudes; municipal officials; ordinances; Pennsylvania; street trees; tree commissions; urban and community forestry.

A survey was conducted in 2005 to determine what causes municipal officials in Pennsylvania, U.S. to provide, or to withhold, support for street tree programs (Stevenson 2006). We wanted to know how knowledgeable the municipal officials are and what their attitudes are toward trees and municipal tree programs. The answers might help to explain why so many communities are reluctant to start or improve tree programs and to find more effective ways by which officials could be persuaded to be more supportive.

Recent surveys of municipal tree programs in other states have been reported for Illinois (Schroeder et al. 2003), Mississippi (Grado et al. 2006), Missouri (Treiman and Gartner 2004), Oregon (Ries et al. 2007), and Utah (Kuhns et al. 2005). They provided information mainly about the status and characteristics of tree programs and included some comments about the attitudes and knowledge of local officials, but not those of solicitors, who can be influential in preparing tree ordinances.

Several studies in Pennsylvania have documented progress in community tree programs since a statewide urban forestry program began in 1991. Reeder and Gerhold (1993) found that only $28 \%$ of cities and boroughs claimed to have tree programs in $1991 ; 57 \%$ of them had a tree commission; and numbers of street trees were declining in $40 \%$ of the municipalities. Still et al. (1996) reported on the effectiveness of grants awarded to communities during 1991 to 1993 by Pennsylvania's Bureau of Forestry and the Urban and Community Forestry Council and also the attitudes of community leaders and volunteers. Grant recipients more often viewed tree planting as a means of improving the attractiveness of communities and taking pride in them compared with unfunded applicants and nonapplicants who were more concerned about safety hazards and nuisances associated with trees. Still and Gerhold (1997) discovered that trained volunteers of four tree organizations in Philadelphia and New York
City regarded tree care as more important and satisfying than tree planting in contrast to potential volunteers who expressed a greater interest in planting. Elmendorf et al. (2003) contrasted attitudes of volunteer tree commission members about their responsibilities compared with their actual practices and accomplishments. Tree ordinances, inventories, management plans, planting, annual inspections, adequate tree care, and removal of hazardous trees all were deemed important by $83 \%$ to $100 \%$ of survey respondents, but only $29 \%$ to $78 \%$ of these tasks had been accomplished. The greatest difficulties in completing the practices were in trying to gain support of community officials and citizens, dealing with turnover of officials and commission members, and time limitations of tree commission volunteers faced with competing interests. The commissioners believed that community leaders and residents did not fully understand the value and benefits of trees, and some had negative attitudes toward trees.

\section{METHODS}

Because municipal officials have a key role in providing support for community tree programs, a survey was conducted to obtain information from three types of officials-elected chief officials, public works administrators, and municipal solicitors-involved in three categories of tree programs defined by the USDA Forest Service: sustained, developing, and undeveloped. The purposes were to:

1. Determine if there are differences in attitudes of the three types of officials toward street tree programs;

2. Define any differences in attitudes among the three categories of programs; and

3. Examine how population size of communities may be related to attitudes. 
A multistage, self-administered questionnaire was mailed in October 2005 to 1,401 officials in a sample of the 57 cities, 960 boroughs, and 1,547 townships in Pennsylvania. These are the three types of municipalities in the Commonwealth of Pennsylvania; most townships are rural, but some are as densely populated as boroughs, which in other states may be called towns or villages.

Penn State's extension urban foresters provided lists of the 120 municipalities that had sustained tree programs and the 125 that were developing programs, all of which were sampled. In the 1991 survey, 378 tree programs were estimated to exist, a larger number because no criteria were applied to determine what constituted a tree program.

In the 2005 survey, the benchmarks of a sustained program were the existence of a street tree ordinance, a tree commission or board, a street tree inventory, and a street tree management plan; a developing program had at least one of these elements and an undeveloped program had none. The survey included all 22 cities, 78 boroughs, and 20 townships that had sustained programs and all nine cities, 93 boroughs, and 23 townships that had developing programs. A lower response rate was anticipated from municipalities that had no tree program, so the random sample of undeveloped programs was elevated and consisted of 156 boroughs and 40 townships, and also all the remaining 26 cities, totaling 222 municipalities.

The three types of officials selected in each municipality represented those who could potentially influence the start or improvement of a tree program. The titles of the officials in each of the three groups varied because of the different governmental structures and traditions of cities, boroughs, and townships. For example, the elected chief official might be a mayor, president of a borough council, or chairman of the township supervisors.

The eight-page questionnaire containing 19 questions was sent with a cover letter that ensured confidentiality to 1,401 officials, three in each of the 467 municipalities; 20 were returned as undeliverable. Wording of the questionnaire was applicable to all three types of officials and to the three types of programs. The first question asked about the existence of eight elements that may occur in street tree programs-a tree commission or board, tree ordinance, inventory, management plan, tree care budget, pruning and removal of trees by a ISA Certified Arborist, Tree City USA, and an Arbor Day celebration-or the likelihood that an element will occur within 3 years. A six-point Likert scale measured the status of these elements, extending from $6=$ currently exists or $5=$ definitely will happen to $3=$ possibly to
1 = will not happen. The next 11 questions, using five-point Likert scales, solicited attitudes toward the importance of eight program elements: how tree programs are organized and funded, benefits and problems associated with trees, obstacles to starting or improving a tree program, legal concerns, and helpfulness of various sources of assistance. Three questions requested specific information about annual spending on municipal trees and asked for a list and ranking of the top five benefits and the top five problems associated with street trees. The last four questions obtained demographic characteristics of the respondent.

The statistical program used for all computations was SPSS version 13.0. $\chi^{2}$ tests examined bivariate relationships between nominal attitudinal questions and survey groups: tree program types, types of officials, and population categories. Significance levels of $0.05,0.01$, and 0.001 designated differences.

\section{RESULTS AND DISCUSSION}

Responses came from 528 people at a rate of $38 \%$ and from 356 municipalities at a rate of $76 \%$. Sustained programs had a higher response rate from individuals $(179=50 \%)$ than did developing $(149=40 \%)$ or undeveloped programs $(215=33 \%)$. Municipal response rates (one or more response from each municipality) were $90 \%$ from 120 municipalities having sustained programs, $80 \%$ from 125 developing programs, and $67 \%$ from the 222 undeveloped programs in the sample. More responses came from public works managers $(242=52 \%)$ than the chief elected officials $(182=39 \%)$ or solicitors $(119=26 \%)$. Response rates from five categories of population size varied with no particular pattern from a low of $71 \%$ coming from the middle size $(5,001$ to 10,000$)$ to $87 \%$ that came from the largest size (over 20,000).

Information about the status of tree programs submitted by municipal officials showed some inconsistencies with the defined categories in which they had been placed by the extension urban foresters. Thus, if the classifications of sustained communities were correct, and if the officials had complete and accurate knowledge about the four elements (a street tree ordinance, street tree inventory, street tree management plan, and a tree commission or board) in their municipalities, all four should have been reported to exist in $100 \%$ of the municipalities, but they were not (Table 1). The existence of an ordinance and tree commission reported by $87 \%$ to $88 \%$ of the respondents from municipalities with sustained tree programs may be close to the truth, because all three types of officials would be expected to know about them. However, the existence of an inventory $(64 \%)$ or manage-

Table 1. Tree program elements in three types of programs and likelihood of adding elements within 3 years. ${ }^{z}$

\begin{tabular}{|c|c|c|c|c|c|c|}
\hline \multirow[b]{2}{*}{ Program element } & \multicolumn{2}{|c|}{ Sustained } & \multicolumn{2}{|c|}{ Developing } & \multicolumn{2}{|c|}{ Undeveloped } \\
\hline & Exists & Likely & Exists & Likely & Exists & Likely \\
\hline Ordinance* & 87 & 7 & 59 & 23 & 35 & 27 \\
\hline Commission* & 88 & 3 & 68 & 12 & 29 & 25 \\
\hline Inventory* & 64 & 25 & 32 & 41 & 9 & 34 \\
\hline Management plan* & 58 & 32 & 27 & 44 & 11 & 41 \\
\hline Budget greater than $\$ 2$ per capita* & 44 & 18 & 19 & 19 & 4 & 15 \\
\hline ISA Certified Arborist* & 46 & 20 & 14 & 28 & 8 & 13 \\
\hline Tree City USA* & 56 & 18 & 26 & 27 & 3 & 19 \\
\hline Arbor Day* & 59 & 20 & 27 & 33 & 8 & 24 \\
\hline Number of respondents & \multicolumn{2}{|c|}{$152-172$} & \multicolumn{2}{|c|}{$125-133$} & \multicolumn{2}{|c|}{$176-190$} \\
\hline
\end{tabular}

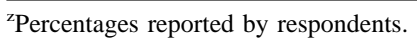

*Significant differences among types of programs at 0.001 level. 
ment plan $(58 \%)$ is less likely to be known by the officials than by the extension foresters, who generally work more closely with tree commissions than with officials. Inventories and management plans typically are prepared by tree commissions, often without the involvement or knowledge of municipal officials.

To the extent that the knowledge of officials was imperfect, inaccuracies would have resulted in the reported percentages of tree program elements. Evidence was indeed found that some municipal officials have incomplete knowledge about tree programs in their communities. In each of 41 cases among the 145 municipalities that returned responses from two or three officials, there were discrepancies among them or inconsistencies with the four classification benchmarks. Furthermore, differences appeared among the three types of officials in the reported existence of program elements (Table 2), which is also an indication that knowledge about their tree programs may be incomplete or not fully understood. The reported existence of benchmark elements in undeveloped programs may indicate that the extension urban foresters were not aware of some developing programs or that their perceptions differed from those of municipal officials as to how functional an element was or the timeframe when it was effective.

The reported existence of a tree ordinance in $35 \%$ of the sample of 26 cities, 789 boroughs, and 1,504 townships, which were classified as undeveloped, also raises the question whether some of them should be reclassified as developing. Presumably that could affect approximately nine cities and 276 boroughs but less than 525 townships because most of them are rural. Classifications were not changed in this study, however, because the knowledge of the extension urban foresters was considered as reliable, whereas the survey responses were subject to various interpretations.

\section{Prevalence of Program Elements}

Although the percentages stating the existence of tree program elements may be somewhat flawed, the relationships among the three types of programs are worth noting. Clearly, there were substantial differences in the reported existence of all eight program elements (Table 1). Five of the elements occurred more commonly in larger municipalities (Table 3). Frequencies of all elements were reported to be higher in sustained programs than in developing programs, which in turn were higher than in undeveloped programs. Developing programs reported that $68 \%$ had tree commissions, 59\% had a tree ordinance, $32 \%$ had an inventory, and $27 \%$ had a management plan.

However, it is encouraging, although unexpected, that $35 \%$ of respondents from communities defined as having no tree program reported having a tree ordinance and $29 \%$ a tree commis- sion or committee. Even if the percentages are inexact, they suggest that many of the municipalities could be encouraged to progress to the developing or sustained stage. In fact, $25 \%$ to $41 \%$ of respondents from undeveloped programs indicated it is likely that an ordinance, tree committee, inventory, or management plan would be completed in the next 3 years (Table 1). The likelihood did not vary much with population size (Table 3), so many of the 26 cities and 789 boroughs that are not known to have tree programs present a great opportunity for progress; most of the 1,504 townships are rural, however, and those commonly have little interest in a tree program.

The calculated percentages of officials who thought it was likely that tree program elements would be added (Table 1) probably are more reliable than the existence percentages, because they depend more on the realistic opinions of officials rather than knowledge about their tree programs. In all three types of programs, there was more than a minimal interest in developing inventories and management plans, $34 \%$ to $44 \%$ in developing and undeveloped programs. Sustained programs should already have these elements, so the reported likely additions probably indicate the updating of inventories and revisions of management plans. Public works directors seemed to take a particular interest in management plans (Table 2). Ordinances and tree commissions scored high among undeveloped programs, which is logical because these are often the first and most important elements when tree programs are initiated. The likelihood of achieving a \$2 per capita budget (15\% to $19 \%$ ) was lower than any other program element, except for the use of ISA Certified Arborists in undeveloped programs (13\%).

\section{Attitudes Toward Municipal Street Trees}

Attitudes of officials can be expected to influence their actions toward starting or improving municipal tree programs. Most officials (79\%), irrespective of type of official, type of program, or population size, agreed that street trees are important in making a community a desirable place to live. The strongest differences in attitudes toward benefits and costs of street trees were associated with the three types of programs (Table 4), more than with types of officials or population sizes. Favorable responses from sustained programs to questions about benefits exceeding costs of tree maintenance or any problems trees may cause, and the need for ordinances, inspections, and budgetary support, ranged from $61 \%$ to $76 \%$. Responses from developing programs were somewhat lower, from $45 \%$ to $68 \%$. Even in undeveloped programs, favorable attitudes ranged from $39 \%$ for budget support to $58 \%$ for an ordinance regulating maintenance and removals.

Officials in all types of programs recognized some need for better information about benefits of trees, especially in undevel-

Table 2. Tree program elements reported by three types of officials and likelihood of adding elements within 3 years. ${ }^{2}$

\begin{tabular}{|c|c|c|c|c|c|c|}
\hline \multirow[b]{2}{*}{ Program element } & \multicolumn{2}{|c|}{ Elected official } & \multicolumn{2}{|c|}{ Public works } & \multicolumn{2}{|c|}{ Solicitor } \\
\hline & Exists & Likely & Exists & Likely & Exists & Likely \\
\hline Ordinance* & 57 & 20 & 64 & 19 & 51 & 17 \\
\hline Management plan* & 37 & 36 & 28 & 43 & 27 & 32 \\
\hline Budget greater than $\$ 2$ per capita* & 23 & 16 & 26 & 18 & 10 & 15 \\
\hline ISA Certified Arborist* & 30 & 20 & 21 & 19 & 13 & 17 \\
\hline Number of respondents & \multicolumn{2}{|c|}{$159-164$} & \multicolumn{2}{|c|}{$221-230$} & \multicolumn{2}{|l|}{$91-96$} \\
\hline
\end{tabular}

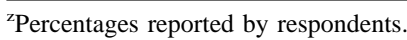

*Significant differences among types of officials at 0.05 level. Differences among other elements were not significant. 
Table 3. Tree program elements in municipalities differing in population size, and likelihood of adding elements within 3 years. $^{2}$

\begin{tabular}{|c|c|c|c|c|c|}
\hline \multirow[b]{2}{*}{ Program element exists } & \multicolumn{5}{|c|}{ Population category } \\
\hline & Less than 2,500 & $2,501-5,000$ & $5,001-10,000$ & $10,001-20,000$ & Greater than 20,000 \\
\hline Ordinance $* * *$ & 45 & 59 & 59 & 67 & 80 \\
\hline Management plan* & 25 & 29 & 38 & 26 & 42 \\
\hline ISA Certified Arborist** & 18 & 11 & 26 & 26 & 40 \\
\hline Tree City USA*** & 23 & 12 & 28 & 37 & 48 \\
\hline Arbor Day*** & 21 & 16 & 34 & 46 & 51 \\
\hline \multicolumn{6}{|l|}{ Element likely to be added } \\
\hline Ordinance $* * *$ & 19 & 19 & 22 & 18 & 13 \\
\hline Management plan* & 36 & 46 & 31 & 45 & 38 \\
\hline ISA Certified Arborist $* *$ & 22 & 24 & 15 & 16 & 17 \\
\hline Tree City USA*** & 17 & 29 & 20 & 17 & 21 \\
\hline Arbor Day*** & 22 & 39 & 23 & 17 & 21 \\
\hline Number of respondents & $129-132$ & $94-108$ & $104-111$ & $70-79$ & $58-61$ \\
\hline
\end{tabular}

${ }^{\text {z}}$ Percentages reported by respondents.

*Significant differences among population sizes at 0.05 level.

**Significant differences among population sizes at 0.01 level.

***Significant differences among population sizes at 0.001 level.

oped programs. Presumably that was because officials perceived that residents did not consider maintenance of trees a high priority ( $8 \%$ to $27 \%$ ) nor that they were willing to pay higher taxes for better tree care (3\% to $9 \%$ ). A larger percentage of solicitors $(67 \%$ to $75 \%)$ had favorable attitudes toward benefits of trees and the need for related information than elected officials $(59 \%$ to $60 \%$ ) or public works officials (52\% to $57 \%$ ). The latter were most supportive of ordinances $(72 \%)$ and budget support $(55 \%)$.

\section{Attitudes Toward Tree Care Practices}

Officials in communities that had sustained tree programs attached greater importance to six tree care practices (65\% to $90 \%)$ than those in developing (50\% to $77 \%$ ) or undeveloped programs (35\% to $73 \%$ ) (Table 5). For every question about tree care, responses from developing programs were intermediate between the other two. In all three types of programs, tree inventories were accorded the lowest values and removal of dangerous trees the highest. Officials seemed to recognize that dangerous trees could be identified by annual inspections, but apparently they were less aware that inventories could be used to plan for tree care practices that would prevent trees from becoming hazardous. Nevertheless, it was apparent that safety was a principal concern. In an Illinois community, support for spending municipal funds was strongest for the removal of hazardous trees (Schroeder et al. 2003).

Questions about pruning elicited a similar pattern of responses (Table 6). The recognition that proper pruning improves the health and structure of trees received high marks from all three types of programs $(95 \%, 91 \%$, and $85 \%)$. However, differences between sustained programs and undeveloped programs were larger in knowing that only a qualified person should prune $(78 \%$ versus $62 \%$ ), benefits of pruning outweigh costs $(62 \%$ versus $41 \%$ ), and that topping is not an appropriate practice (58\% versus $42 \%)$.

\section{Sources of Assistance for Tree Work}

Support for tree programs from the various sources of assistance-financial, technical, and time contributed by volunteers-appeared to be low (Table 7). Sustained programs availed themselves of all kinds of assistance to a greater extent than developing programs, yet even undeveloped programs had some assistance for work on trees. Municipal budgets were a principal means of support $(59 \%)$ for sustained programs as were volunteers $(57 \%)$. In developing programs, volunteers were more im-

Table 4. Attitudes toward street trees by type of tree program. ${ }^{2}$

\begin{tabular}{|c|c|c|c|}
\hline \multirow[b]{2}{*}{ Statements about street trees } & \multicolumn{3}{|c|}{ Type of program } \\
\hline & Sustained & Developing & Undeveloped \\
\hline Benefits of street trees outweigh any problems they cause** & 76 & 60 & 49 \\
\hline Ordinance is needed to regulate maintenance and removal of street trees* & 74 & 68 & 58 \\
\hline Benefits of street trees outweigh maintenance costs** & 71 & 59 & 46 \\
\hline Municipal budget should support planting, maintenance, and removal of street trees* & 62 & 52 & 39 \\
\hline Inspections for hazardous street trees would reduce municipal liability* & 61 & 45 & 43 \\
\hline Officials need more information about benefits of street trees to a municipality* & 52 & 59 & 69 \\
\hline Residents of our municipality consider tree maintenance a high priority** & 27 & 21 & 8 \\
\hline Residents would be willing pay higher taxes for better tree care** & 9 & 7 & 3 \\
\hline Number of respondents & $168-170$ & $134-139$ & $191-202$ \\
\hline
\end{tabular}

${ }^{\mathrm{z}}$ Percentages of respondents who agreed with statements.

*Significant differences among types of programs at 0.01 level.

**Significant differences among types of programs at 0.001 level. 
Table 5. Attitudes toward tree care practices by type of tree program. ${ }^{z}$

\begin{tabular}{|c|c|c|c|}
\hline \multirow[b]{2}{*}{ Importance of tree care practices } & \multicolumn{3}{|c|}{ Type of program } \\
\hline & Sustained & Developing & Undeveloped \\
\hline Annual removal of dangerous street trees* & 90 & 77 & 73 \\
\hline Annual inspections to find unhealthy or dangerous street trees* & 84 & 70 & 60 \\
\hline Standards applied for pruning, planting, and removals* & 84 & 71 & 55 \\
\hline Ordinance specifies responsibilities for planting, pruning, and removals* & 81 & 66 & 54 \\
\hline Tree commission manages tree care practices* & 79 & 67 & 43 \\
\hline Inventory quantifies species, tree condition, and work needs* & 65 & 50 & 35 \\
\hline Number of respondents & $170-173$ & 137-139 & $195-200$ \\
\hline
\end{tabular}

${ }^{2}$ Percentages of respondents who regarded them as important.

*Significant differences among types of programs at 0.001 level.

portant than municipal budgets (43\% versus 35\%). Donations and fundraising supplemented them but were deemed less important than urban forestry grants (37\%). Also important to both sustained programs and developing programs was technical assistance by Penn State extension urban foresters (50\% and $45 \%$ ) and by the Bureau of Forestry (35\% and $31 \%$ ). Lack of technical assistance was much more important to municipalities below 10,000 in population size ( $52 \%$ to $53 \%$ ) than to larger ones $(30 \%$ to $38 \%$ ).

\section{Attitudes about Municipal Responsibilities for Tree Programs}

How influential are the attitudes of officials in shaping municipal tree programs? Research has shown that adequate funding for tree programs can be achieved where officials perceive that residents are supportive (Robeson 1984; Elmendorf et al. 2003). The decisions of officials are based on their perceptions of reality, i.e., what they believe to be true, more than on factual information about trees (Geiger 2005).

Officials who have sustained or developing tree programs were more supportive compared with those who have no program (Table 8). So it could be inferred that their support contributed to the success of the programs. In sustained programs, $84 \%$ of officials believed improvements can be made; presumably the other $16 \%$ were satisfied with their programs or were disinterested. However, even in municipalities with nonexistent programs, $62 \%$ were in favor of starting a tree program. Supportive officials apparently are motivated by more than creating a positive legacy as indicated by the lower percentages. Those who believed the start or improvement of a municipal tree program can be achieved also were at lower percentages, $42 \%$ to $68 \%$. Only $20 \%$ to $42 \%$ believed a well-funded tree program is important compared with other municipal programs. Part of the reason probably is that only $12 \%$ to $44 \%$ thought that strong public support for a street tree program exists in their municipality.

Nevertheless, $60 \%$ to $85 \%$ favored spending municipal funds for planting, pruning, and removal of street trees. However, also, $41 \%$ to $55 \%$ proposed that adjacent property owners should be responsible for planting, pruning, and removals. Apparently officials believed the costs of planting and maintaining street trees should be shared by the municipality and adjacent property owners. Another reason sometimes given, but not a valid one in Pennsylvania, is the assumption that a municipality can avoid liability for damage caused by trees by making property owners responsible for tree care. Only $9 \%$ to $19 \%$ believed that planning and caring for street trees is not the role of their municipality.

Many officials, $47 \%$ to $66 \%$, claimed that more information is needed before starting or improving a program. Those responses are consistent with their attitudes, $52 \%$ to $69 \%$ (Table 4), that they needed more information about the benefits of street trees to a municipality.

\section{Barriers to Starting or Improving Tree Programs}

Some of the barriers to starting or improving tree programs were regarded as equally important by all three types of officials (Table 9): insufficient funding (by 86\%), a lack of personnel (70\%), inadequate equipment $(67 \%)$, and low public support $(62 \%)$. Lack of funding was also the most important barrier in a Mississippi study (Grado et al. 2006). Elected officials and public works directors $(69 \%$ to $70 \%)$ were more concerned than solicitors $(57 \%)$ about tree-related problems such as raised sidewalks, cleanup of leaves in the fall, and nuisance birds, perhaps because they were more likely to hear complaints from their constituents. Solicitors were the least concerned about liability (37\%) and more about lack of technical assistance and information $(59 \%)$ compared with the other officials. Some municipal officials do not realize that Pennsylvania municipal codes make

Table 6. Attitudes toward pruning of street trees by type of tree program. ${ }^{z}$

\begin{tabular}{|c|c|c|c|}
\hline \multirow[b]{2}{*}{ Statements about pruning } & \multicolumn{3}{|c|}{ Type of program } \\
\hline & Sustained & Developing & Undeveloped \\
\hline Proper pruning improves health, structure* & 95 & 91 & 85 \\
\hline Only a qualified person should prune* & 78 & 70 & 62 \\
\hline Benefits of pruning outweigh costs** & 62 & 47 & 41 \\
\hline Topping is not an appropriate practice* & 58 & 44 & 42 \\
\hline Number of respondents & $169-172$ & $134-138$ & $195-196$ \\
\hline
\end{tabular}

${ }^{\mathrm{z} P e r c e n t a g e s}$ of respondents who agreed with statements.

*Significant differences among types of programs at 0.01 level.

**Significant differences among types of programs at 0.001 level. 
Table 7. Helpful sources of assistance to three types of tree programs during the past 3 years. ${ }^{2}$

\begin{tabular}{llll}
\hline & & \multicolumn{2}{c}{ Type of program } \\
\cline { 2 - 4 } Helpful sources of assistance & Sustained & Developing & Undeveloped \\
\hline Municipal budget** & 59 & 35 & 19 \\
Volunteers** & 57 & 43 & 23 \\
Technical assistance, Penn State Extension** & 50 & 37 & 20 \\
Urban forestry grants** & 46 & 22 & 19 \\
Local donations** & 37 & 31 & 15 \\
Technical assistance, Bureau of Forestry** & 35 & 11 & 16 \\
Fundraising* & 16 & $125-136$ & 11 \\
Number of respondents & $154-170$ & $182-188$ \\
\hline
\end{tabular}

${ }^{2}$ Percentages of respondents who regarded them as helpful.

*Significant differences among types of programs at 0.01 level.

**Significant differences among types of programs at 0.001 level.

boroughs responsible for the care of public trees along the public right-of-way and ignoring them does not relieve the municipality of exposure to liability.

\section{CONCLUSIONS}

In Pennsylvania, the lack of street tree programs in $46 \%$ of 57 cities, $82 \%$ of 960 boroughs, and $97 \%$ of 1,547 townships indicates there are many opportunities, but also barriers, to starting or improving tree programs. Attitudinal differences between municipal officials who have tree programs, compared with those with none or incompletely developed programs, suggest ways by which the start or improvement of a municipal program could be promoted.

Officials with sustained programs had more positive attitudes toward the importance of trees than in developing or undeveloped programs, especially in larger municipalities. They reported stronger public support and agreed that adequate financial support and annual inspections for hazardous trees were needed.

However, even in communities with undeveloped programs, approximately half of the officials believed that benefits of street trees outweigh the costs and that benefits outweigh problems associated with trees; $62 \%$ of them favored starting a tree program. Among all respondents, $79 \%$ agreed that street trees were important in making a community a more desirable place to live.

Several reasons emerged to explain why officials do not support tree programs. Only $20 \%$ to $42 \%$ regard a well-funded tree program to be as important as other municipal responsibilities. Many municipalities are financially distressed. If officials per- ceive that residents will not support a tree program or a tax increase for tree care, they are unwilling to divert resources from other needs considered to be more important. Most realize they need more education, including information about technical matters and benefits of trees that extend beyond shade and attractiveness to environmental and economic values for residents, businesses, and property owners. Many are unaware of grants or technical assistance that is available. Reducing municipal exposure to liability resulting from hazardous trees is seldom considered to be a convincing argument for a tree program, but public safety definitely is.

The most helpful sources of assistance for supporting tree care were funding by the municipal budget, contributions by volunteers, and technical assistance by professional foresters; technical assistance by extension and state forestry employees was especially important to the smaller communities. Relating public safety to benefits of pruning, inventories, and removing hazardous trees can be especially persuasive, because $71 \%$ felt that annual inspections to find dangerous trees were important and $80 \%$ favored removal of hazardous trees.

Public works administrators were slightly more likely to be supportive than elected officials or solicitors. However, the type of official appears to be less important than finding one who has a favorable attitude and a willingness to support a tree program, because relatively minor differences were found among the three types of officials.

The findings suggest a three-pronged strategy for persuading municipal officials to start a tree program or improve an existing

Table 8. Attitudes about municipal responsibilities for tree programs by type of program. ${ }^{z}$

\begin{tabular}{|c|c|c|c|}
\hline \multirow[b]{2}{*}{ Statements about street tree programs } & \multicolumn{3}{|c|}{ Type of program } \\
\hline & Sustained & Developing & Undeveloped \\
\hline I favor spending municipal funds for planting, pruning, and removal of street trees* & 85 & 67 & 60 \\
\hline I favor starting or improving a tree program in my municipality* & 84 & 78 & 62 \\
\hline It is achievable to start or improve a program in my municipality* & 68 & 60 & 42 \\
\hline My support for a municipal tree program can create a positive legacy* & 64 & 56 & 41 \\
\hline We need more information before starting or improving a program* & 47 & 49 & 66 \\
\hline Strong public support for a street tree program exists in my municipality* & 44 & 32 & 12 \\
\hline A well-funded tree program is important compared with other municipal programs* & 42 & 27 & 20 \\
\hline Adjacent property owners should be responsible for planting, pruning, and removals* & 41 & 53 & 55 \\
\hline Planning and caring for street trees is not the role of my municipality* & 9 & 15 & 19 \\
\hline Number of respondents & $170-175$ & $137-140$ & $200-202$ \\
\hline
\end{tabular}

${ }^{\text {z}}$ Percentages of respondents who agreed with statements.

*Significant differences among types of programs at 0.001 level. 
Table 9. Barriers to the start or improvement of a street tree program perceived by three types of officials. ${ }^{z}$

\begin{tabular}{llll}
\hline & \multicolumn{3}{c}{ Type of official } \\
\cline { 2 - 4 } Barriers to programs & All three & Elected official & Public works \\
\hline Insufficient funding & 86 & & Solicitor \\
Personnel lacking & 70 & & \\
Inadequate equipment & 67 & & 69 \\
Low public support & 62 & 70 & 60 \\
Tree problems: leaf-fall, sidewalks, birds* & & 55 & 39 \\
Liability concerns* & & 51 & 41 \\
Technical assistance needs* & & 46 & 37 \\
Lack of information* & $493-498$ & $167-168$ & 59 \\
Number of respondents & & & 59 \\
\hline
\end{tabular}

${ }^{\mathrm{z}}$ Percentages of respondents who considered them important.

*Significant differences among types of officials at 0.01 level.

program. First, residents could be organized and educated to demonstrate strong support for tax-based funding for a tree program. Ideally, a local resident who has a strong commitment to trees and community pride would organize that effort, aided by a few volunteers, and could use assistance available from extension urban foresters in Pennsylvania. Second, when officials have recognized that strong public support has developed, they should be reminded of the economic, environmental, and safety benefits that can be realized from an effective street tree program and the technical assistance that is available. Third, officials should be asked to provide adequate funding and make provisions for the four main program elements: an ordinance, tree commission, inventory, and management plan. Most officials do have an appreciative outlook on trees. Favorable times for promoting a street tree program are just after an emergency involving trees has occurred or at the start of an election campaign; that is based on personal experience, not on the survey.

Acknowledgments. Partial support was provided by the USDA Forest Service, Northeastern Area State and Private Forestry through the Pennsylvania Urban and Community Forestry Council.

\section{LITERATURE CITED}

Elmendorf, W.F., V.J. Cotrone, and J.T. Mullen. 2003. Trends in urban forestry practices, programs and sustainability: Contrasting a Pennsylvania, U.S. study. Journal of Arboriculture 29:237-247.

Geiger, J.R. 2005. Politicians and the tree vote. City Trees 41:8-12.

Grado, S.C., D.L. Grebner, M.K. Measells, and A.L. Husak. 2006. Status, needs, and knowledge levels of Mississippi's communities relative to urban forestry. Arboriculture and Urban Forestry 32:24-31.

Kuhns, M.R., B. Lee, and D.K. Reiter. 2005. Characteristics of urban forestry programs in Utah, U.S. Journal of Arboriculture 31:285-294.

Reeder, E.C., and H.D. Gerhold. 1993. Municipal tree programs in Pennsylvania. Journal of Arboriculture 19:12-19.

Ries, P.D., A.S. Reed, and S.J. Kresse. 2007. The impact of statewide urban forestry programs: A survey of cities in Oregon, U.S. Arboriculture and Urban Forestry 33:168-175.

Robeson, H.L. 1984. Urban forestry in the Chicago suburbs. Journal of Arboriculture 10:113-116.

Schroeder, H.W., T.L. Green, and T.J. Howe. 2003. Community tree programs in Illinois, U.S.: A statewide survey and assessment. Journal of Arboriculture 29:218-225.

Stevenson, T.R. 2006. Attitudes of officials toward municipal street tree programs. Pennsylvania State University, MS Thesis. 125 pp.

Still, D., B. Fair, and H. Gerhold. 1996. Community forestry grants in Pennsylvania: How effective are they? Journal of Forestry 94:26-30.
Still, D.T., and H.D. Gerhold. 1997. Motivations and task preferences of urban forestry volunteers. Journal of Arboriculture 23:116-130.

Treiman, T., and J. Gartner. 2004. Community forestry in Missouri, U.S.: Attitudes and knowledge of local officials. Journal of Arboriculture 30:205-212.

Tyler R. Stevenson

1624 North Coast Highway, \#25

Encinitas, CA 92024, U.S.

Tyler219@gmail.com

Henry D. Gerhold (corresponding author)

Professor of Forest Genetics

333 Forest Resources Building

Penn State University

University Park, PA 16802, U.S.

hdg@psu.edu

William F. Elmendorf

Assistant Professor of Urban and Community Forestry

334 Forest Resources Building

Penn State University

University Park, PA 16802, U.S.

wfe1@psu.edu

Résumé. Les réponses d'une enquête provenant de 528 responsables au sein de 356 municipalités ont permis d'évaluer l'état du développement des programmes municipaux d'arbres de rues ainsi que les attitudes de trois types de décideurs: les élus en chef, les administrateurs de travaux publics et les conseillers municipaux. Dans les programmes soutenus qui comportent une réglementation, une commission de l'arbre, un inventaire et un plan de gestion, les décideurs ont une attitude plus positive envers les arbres que dans les communautés où les programmes sont en cours de développement - c'est-à-dire qui ont au moins l'un de ces éléments -, ou encore celles sans programme pour les arbres. Mais même dans le dernier cas, environ la moitié des décideurs croient que les bénéfices des arbres outrepassent les coûts et les désavantages, et $62 \%$ favorisent le démarrage d'un tel programme. Il n'existe pas de programme pour les arbres dans $46 \%$ des villes, $82 \%$ des banlieues et $97 \%$ des villages; il y a donc plusieurs opportunités mais aussi d'importantes barrières. Une compréhension incomplète des bénéfices des arbres et des pratiques d'entretien mène à un faible support public, une insuffisance de fonds ainsi qu'un personnel et des équipements inadéquats. La plupart des décideurs favorisent le déboursé de certains montants pour les arbres, mais ils jugent les programmes pour les arbres moins importants que d'autres responsabilités civiques. Les décideurs peuvent être per- 
suadés de démarrer ou d'améliorer les programmes pour les arbres, et ce en expliquant mieux les bénéfices retirés et aussi comment la sécurité du public peut être accrue par un élagage adéquat, des inventaires qui identifient les arbres dangereux et des plans de gestion pour sécuriser le tout. De même, le financement peut être allégé en faisant appel à des volontaires, des campagnes de souscription et des avis techniques.

Zusammenfassung. Die Antworten einer Umfrage unter 528 Beamten aus 356 größeren Kommunen definieren den Entwicklungsstand von kommunalen Straßenbaumprogrammen und das Einstellung von drei verschiedenen Verantwortlichen: gewählte Bürgermeister, mit Öffentlichkeitsarbeit Beauftragte und kommunale Anwälte. In nachhaltigen Programmen, welche eine Baumkommission, Baumkataster und Managementplan beinhalteten, hatten die Verantwortlichen eine positivere Einstellung zu Bäumen, als in Entwicklungsprogrammen, die nur eine Komponente enthielten, oder in Kommunen ohne jegliche Baumprogramme. Aber selbst im letzteren Fall glaubte die Hälfte der Verantwortlichen, dass die Vorteile von Straßenbäumen gegenüber Kosten und jeglichen Nachteilen überwiegen und $62 \%$ sprachen sich für ein Straßenbaumprogramm aus. In $46 \%$ aller Städte, in $82 \%$ der Bezirke und in $97 \%$ der Stadtgemeinden gibt es kein Baumprogramm. Es gibt also viele Möglichkeiten, aber auch wichtige Barrieren. Ohne umfassendes Verständnis für die Vorteile von Bäumen und deren Pflege führt zu geringerer Akzeptanz in der Öffentlichkeit, fehlenden Mittel und ungenügendem Personal und Ausstattung. Die meisten Verantwortlichen bevorzugen, einige Mittel für Bäume aufzuwenden, aber halten Baumprogramme für weniger wichtig als andere öffentliche Verantwortlichkeiten. Die Verantwortlichen müssen ermutigt werden, Baumprogramme zu starten und zu verbessern, indem ihnen die Vorteile näher gebracht werden, wie die öffentliche Sicherheit durch bessere Schnitttechniken verbessert werden kann, wie Baumkataster Gefahren- bäume identifizieren können und Managementpläne eine Entfernung dieser Bäume gewährleisten können. Darüber hinaus können durch Freiwilligen-Programme, Fördermittel und mögliche technische Unterstützung die Kosten vermindert werden.

Resumen. Las respuestas a una encuesta de 528 oficiales en 356 municipalidades definieron el estado de desarrollo de los programas municipales para los árboles, y las actitudes de tres tipos de oficiales jefes electos, administradores públicos y agentes municipales. En programas sostenidos, los cuales tenían una ordenanza, una comisión de arbolado, inventario y plan de manejo, lo oficiales tuvieron actitudes más positivas acerca de los árboles que en programas de desarrollo, los cuales tuvieron al menos uno de estos elementos, o en comunidades sin un programa. Pero aún en los últimos, cerca de la mitad de los oficiales creyeron que los beneficios de los árboles urbanos sobrepasaban a los costos y cualquier otra desventaja, y $62 \%$ favoreció empezar un programa de árboles. No existen programas de árboles en 46 por ciento de las ciudades, 82 por ciento de los distritos, y 97 por ciento de los barrios, por lo que hay muchas oportunidades y también barreras importantes. El incompleto entendimiento de los beneficios de los árboles y las prácticas de cuidado conducen a un bajo apoyo público, insuficiente financiamiento, y personal y equipamiento inadecuados. La mayoría de los oficiales favorecen el gasto de más dinero en los árboles, pero miran los programas de árboles como menos importantes que otras responsabilidades cívicas. Los oficiales pueden ser persuadidos de empezar o mejorar los programas de árboles mediante la explicación de los beneficios más ampliamente, y cómo la seguridad pública puede ser mejorada con la poda apropiada, inventarios que ubiquen árboles peligrosos, y planes de manejo que ordenen su remoción. De allí también que el financiamiento puede ser aliviado utilizando voluntarios, donaciones y recomendaciones técnicas disponibles. 